\title{
SOME NOTES, AND DESCRIPTIONS OF FOUR NEW DIPTERA.
}

BY CHAS. W. JOHNSON, BOSTON, MASS.

\section{Tabanus (Therioplectes) hinei, n. n.}

Therioplectes being now considered at most only a subgenus of Tabanus necessitates the changing of Therioplectes politus Johnson (Entom. News, XI, 325, 1890) which is preoccupied in the genus Tabanus by $T$. politus Walker (The Entomologist, $\mathrm{V}, 256, \mathrm{r} 87 \mathrm{I})$. I therefore propose for this species the new name Tabanus hinei in honor of Prof. Jas. S. Hine, who is making a special study of the Tabanidae.

During the past summer I have obtained four specimens of this species. Two males, Bridgewater, Mass., July I I, collected by Mr. Jos. A. Cushman, and two females, Woods Holl, July 25, and Auburndale, Mass, July 12, collected by the writer. The $q$ which has not been described, differs but little from the $\delta$ in general appearance except that the dorsal stripe of the abdomen is somewhat broader, with a slight dorsal spot or triangle on segments one to four, due chiefly to a small tuft of white hair, readily denuded. One of the males also shows a tuft of white hair on the second segment. Since writing the above $I$ have seen three males of this species from Massachusetts, in the Museum of Comparative Zoölogy, Cambridge, one of which was labeled by Osten Sacken, "male of an unknown species."

\section{Tabanus (Therioplectes) whitneyi sp. nov.}

9. Face, front and palpi reddish brown, frontal callus dark brown, narrowly triangular and extending as a narrow line to the base of the prominent ocelligerous tubercle; a space between the frontal callus and base of the antennae red; antennae red, third joint not excised, and showing no trace of a projecting angle; eyes apparently glabrous and a uniform brown, moisture failing to reveal the greenish bands so characteristic of the group. Thorax reddish brown, with grayish pollen forming four longitudinal stripes interrupted at the transverse suture, the two median stripes extending to the scutellum as a single dorsal line; pleurae reddish with gray pollen and red pile; scutellum brownish black, sides red. Abdomen reddish brown, a broad dorsal stripe and a wide lateral margin on all the segments, dark brown; the third and iourth segments bears a large quadrate central whitish area, the third having anteriorly a black triangle and the fourth a dorsal stripe, dividing it equally and leaving two regular squares; taking both segments together the maculation 
resembles a large letter $\mathrm{H}$. Wings hyaline, veins margined with brown. Length, $19 \mathrm{~mm}$.

8. Face and front reddish brown except the upper triangular portion of the latter which is bright red. Eyes minutely pubescent, ocelligerous tubercle very conspicuous. Pile of the thorax larger than in the female but the stripes less clearly defined. Abdomen a uniform reddish brown and the markings on the third and fourth segments less distinct: the brown margins of the veins are also less pronounced. Length, $\mathrm{r} 7 \mathrm{~mm}$.

The $\&$ collected by Mr. Albert P. Morse, at Wellesley, Mass., is in the New England collection of the Boston Society of Natural History. The $\delta$ marked "N. Y." (Osten Sacken), is in the Museum of Comparative Zoölogy, Cambridge. This peculiar species, with unicolorous eyes, prominent ocelligerous tubercle, and non excised antennae, connects more closely Therioblectes and Taluanus. Dedicated to Mr. C. P. Whitney of Milford, N. H., an enthusiastic student of the Tabanidae.

\section{Anastoechus nitidulus Fabr.}

Anastoechus barbatus Osten Sacken, Western Dipt. Bull. U. S. Geol. Sur. III, 252,1897 .

The distribution of this species in North America is somewhat peculiar. Baron Osten Sacken based his description chiefly on specimens from Wyoming, Colorado and California and also records a specimen from Nantucket collected by Mr. S. H. Scudder, the middle of September. Several years ago I received from the late Andrew Bolter for determination a specimen also taken at Nantucket. Specimens have also been collected by Mr. Samuel Henshaw. Recently in going over a collection of Diptera from Mr. A. P. Morse, I was interested in seeing several specimens from Provincetown, Mass., collected Sept. 8, r89o, and Sept. 5, I89r. Aside from the Massachusetts records I know of no other captures east of Wyoming and Colorado. It is apparently common throughout the Rocky Mts. and Pacific States. I have specimens from Phoenix, Ariz., and Ellensburg, Wash., while Messrs. Viereck and Rehn collected it in numbers in the Sacramento Mts., New Mexico. Mr. Coquillett (Trans. Amer. Ent. Soc. XXI r ro) considers A. barbatus O. S. a synonym of $A$. nitidulus $\mathrm{Fabr}$. of Europe.

Opsebius pterodontinus Osten Sacken, Berl. Entom. Zeit. XXVII, 299, 1883.

Opsebius agelenae Melander, Fntom. News, XIII, 180, 1902.

In looking over the collection of insects at the Peabody Museum, Salem, Mass.. I was somewhat surprised to see a specimen of this species bearing the following label: "Massachusetts, Packard Coll." The specimen having been exposed to 
the light for a number of years, the pile is much lighter than on a specimen in my collection from "N. IIl.," and the abdomen is reddish brown not blackish brown. The wings of the two specimens show a marked difference in venation, the cross vein dividing the first posterior cell is wanting in the specimen from Illinois. $\mathrm{Mr}$. Melander refers to the position of this vein as inconstant. The Massachusetts specimen has the projection on the costa very pronounced, with the sides nearly parallel, apex truncate, edges narrowly margined, and the center hyaline; in the other specimen the projection is conical and the costa more thickened.

The distribution of this rare species, based on six specimens, is as follows: Type from Dallas, Tex., Sept. 20; Austin, 'Tex., and Rochester, Wis. (Melander); N. Ill. (Bolter), Mass. (Packard). The $q$ is unknown. One of the Texas specimens was found by Mr. Melander entangled in web of Agelcna naevia Bosc., having apparently issued from the shrivelled spider lying close by. The above synonymy was given by Dr. C. F. Adams in the Kansas Univ. Sci. Bull., XII, 32, 1903.

\section{Acrocera fasciata Wiedemann.}

Two specimens which agree in every respect with the brief description given by Wiedemann were bred from Lycosa stonei by Dr. T. H. Montgomery, Jr. (Proc. Acad. Nat. Sci. Phila. I903, p. 68) who refers to the parasites as follows:- "One male and six females died from the effects of an endoparasitic dipterous larva. One spider contained two of these parasites, the uthers one each. After the parasite, whose bulk nearly equals that of the body of the spider, has eaten away most of the soft parts of the spider, it emerges through a hole it makes in the wall of the abdomen of the spider, and this imergence kills the host. It is strange that these spiders should live so long with such a huge parasite within them. A short time before the parasite escapes the spider acts in a peculiar manner, walking about spasmodically and often spinning aimlessly."

The larva is light yellow, $5 \mathrm{~mm}$. in length, and resembles the figure given by Mr. J. H. Emerton (Psyche V, 404, 1890,) except that is more contracted towards the head, probably due to the alcohol in which it is preserved. The posterior half is globular in form, the anterior half showing quite clearly segmentation, and bear seven short, transverse, blackish, bristly roughened, pseudopodal ridges; on the posterior portion the ridges are usually divided and indicated by two small spots. The mouth parts show a mandibular structure.

The spiders from which Dr. Montgomery bred this species were collected in or near Philadelphia, $\mathrm{Pa}$., and the two flies obtained, measure respectively 4 and 6 
$\mathrm{mm}$, a specimen from $\mathrm{N}$. Illinois measures only $3 \mathrm{~mm}$. Wiedemann's specimen came from Georgia. The larva described and figured by Mr. Emerton were taken at Waltham, Mass., in the spring of 1887 , from the web of Amaurobius sylicestris, but he was unable to raise the adult fly. In May, 1889 , he again visited the same locality and found several specimens in abandoned cobwebs and from a pupa succeeded in obtaining a fly of which an excellent figure is given, and I agree with Dr. Williston in referring it to Acrocera fasciata Wied.

\section{Oncodes albiventris sp. nov.}

Head black, antennae yellow. Thorax and scutellum black, shining, and covered with erect yellowish pile. Abdomen white, and marked with black as follows:- first segment with a large dorsal spot, the other segments with a short transverse basal band, which extends only over the dorsal third, and from which projects posteriorly, except on the last segment, a short dorsal triangle; third and fourth segments with a smail spot on each side of the dorsal line near the posterior margin; all the segments with a small lateral triangle, most prominent on the last three segments; venter white, with a single transverse band on the last segment; the entire abdomen sparsely covered with whitish hairs. Legs yellow, coxae and basal half of the femora black, tips of the tarsi brownish. Wings hyaline, veins light yellow, tegulae whitish with a narrow hyaline margin. Length, $5 \mathrm{~mm}$.

One specimen, Toronto, Ontario, Canada, July I $8,1896$.

\section{Argyra aldrichi sp. nov.}

8. Face, front and vertex silvery white, the latter about double the width of the face; cilia of the upper orbits black, and of the lateral and inferior orbits white. Antennae black, third joint slightly but evenly tapering to a blunt point, insertion of the arista almost apical. Thorax and scutellum shining green, humeri, pleurae and metanotum thickly covered with a whitish bloom. Abdomen slender, largely yellow, with black hairs, segments 2 to 4 , narrowly margined with black, segments 5 and 6 black, with a white basal band; hypopygium black, the base of the small lamellae yellow. Coxae and legs light yellow, with delicate black hairs and bristles, hind tarsi black, outer portion of the front and middle tarsi brownish. Wing tinged with yellowish-gray, end of the fourth longitudinal vein but slightly inflected forward. Length, $5 \mathrm{~mm}$.

One specimen, woods at Goose Neck, Shrewsbury River, near Long Branch, N. J., June II, 1902. 
Resembles $A$. calceata Loew, but the shape of the third antennal joint, and long, narrow abdomen without whitish bloom, distinguish this species. Dedicated to Prof. J. M. Aldrich, who has done so much to further our knowledge of the Dolichopadidae.

\section{Platypeza (Calotarsa) ornatipes Townsend.}

Calotarsa ornatipes Town., Can. Entom. XXVI, 50, 102; Platypeza ornatipes Banks, l. c. p. 88 ; Coquillett, l. c. 102 ; Williston, l.c. p. I16; Snow, Kans. Univ. Quar. III, 143, 207 ; Johnson, Ent. News, VIII, 254.

Among some Diptera collected by Mr. Owen Bryant on board the schooner "Sunshine" five miles east of the Isles of Shoals, Sept. 5, 1903, were thirteen specimens of this interesting species. Only the $\delta$ is known, and readily recognized by its remarkably exaggerated and elaborate hind tarsi. Later (Oct. r.) I secured one specimen an the window of the Museum of the Boston Society of Natural History. Described from Illinois, and later recorded from Ithaca, N. Y.; Brookings, S. D., and North Mt., Pa., Sept. 3, 1897; this is the first New England record.

Mr. Bryant also captured on the schooner, associated with the above species, Platypeza pallipes Loew, $P$. obscura Lw. and P. velutina Lw. Strong westerly winds prior to that date had undoubtedly blown them from the mainland.

On Sept. 24, four specimens of Platypeza pallipes were taken on the windows of the Museum ; two specimens of P. obscura at Auburndale, Mass., Sept. 13 , and several specimens of $P$. velutina at Dedham, Cohasset and Auburndale, Mass., Sept. 4-20. The latter species has been bred by Prof. Roland Thaxter from Agaricus campestris. The pupa is flat, oval, with jointed thread-like processes on the sides of the segments; the larva is probably very similar.

\section{Alophora magnapennis sp. nov.}

9. Face and front whitish, with white pubescence; vertex and a lunate spot above the base of the antennae brown, from the ends of the latter a brown line extends half way down the face; vibrissae black; antennae brown. Thorax black, prothorax with yellowish pubescence, divided by four black lines (the remainder of the thorax too much disfigured to describe). Abdomen bright red, covered with fine black hairs which are longer on the sides; all the segments bear a pollinose lateral margin. Legs reddish, with black hairs, on the under side of the basal half of the femora the hairs are white. Wings very broad, the costa excessively arcuate, grayish hyaline with dark brown covering the following portions:- the costal cells except a small triangle just before the tip of the first longitudinal vein, outer two- 
thirds of the marginal, and the anterior and apical two-thirds of the submarginal cells, from the latter it extends broadly on each side of the apical cross vein, fourth longitudinal and posterior cross vein slightly beyond the fifth longitudinal vein, it also extends inward along the fourth longitudinal and anterior cross vein, leaving only the central portion of the first posterior and the basal posterior half of the discal cell hyaline. Calypteres whitish margined with yellow. Length, $12 \mathrm{~mm}$.

One specimen, Montreal Island, Canada, from Mr. G. Chagnon. Its large size and broad, maculated wings readily distinguish this species.

Identification of Specimens. - The Cambridge Entomological Club is prepared to undertake the identification of adult forms in all orders, free of charge, for paid-up subscribers to Psvche. The privilege of retaining specimens after identification, for insertion in the collection of the Boston Society of Natural History, is reserved. Each specimen submitted should therefore have a label bearing a number or other distinguishing mark, and the sender should keep a memorandum of these labels.

A Department of Bibliography will be instituted in the next number of Psyche. Brief references to current entomological literature will be presented. This department will hereafter be a regular feature of the journal. 

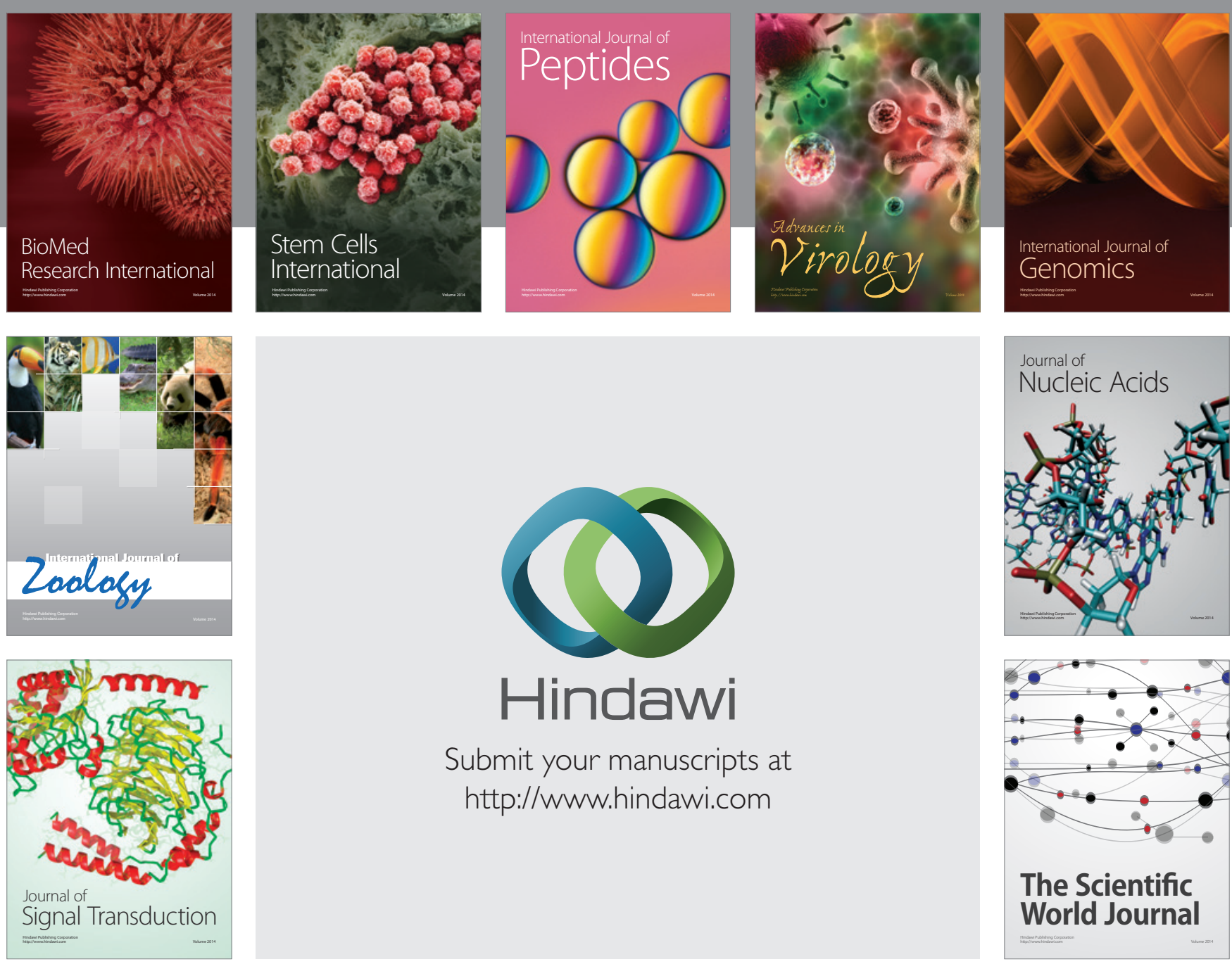

Submit your manuscripts at

http://www.hindawi.com
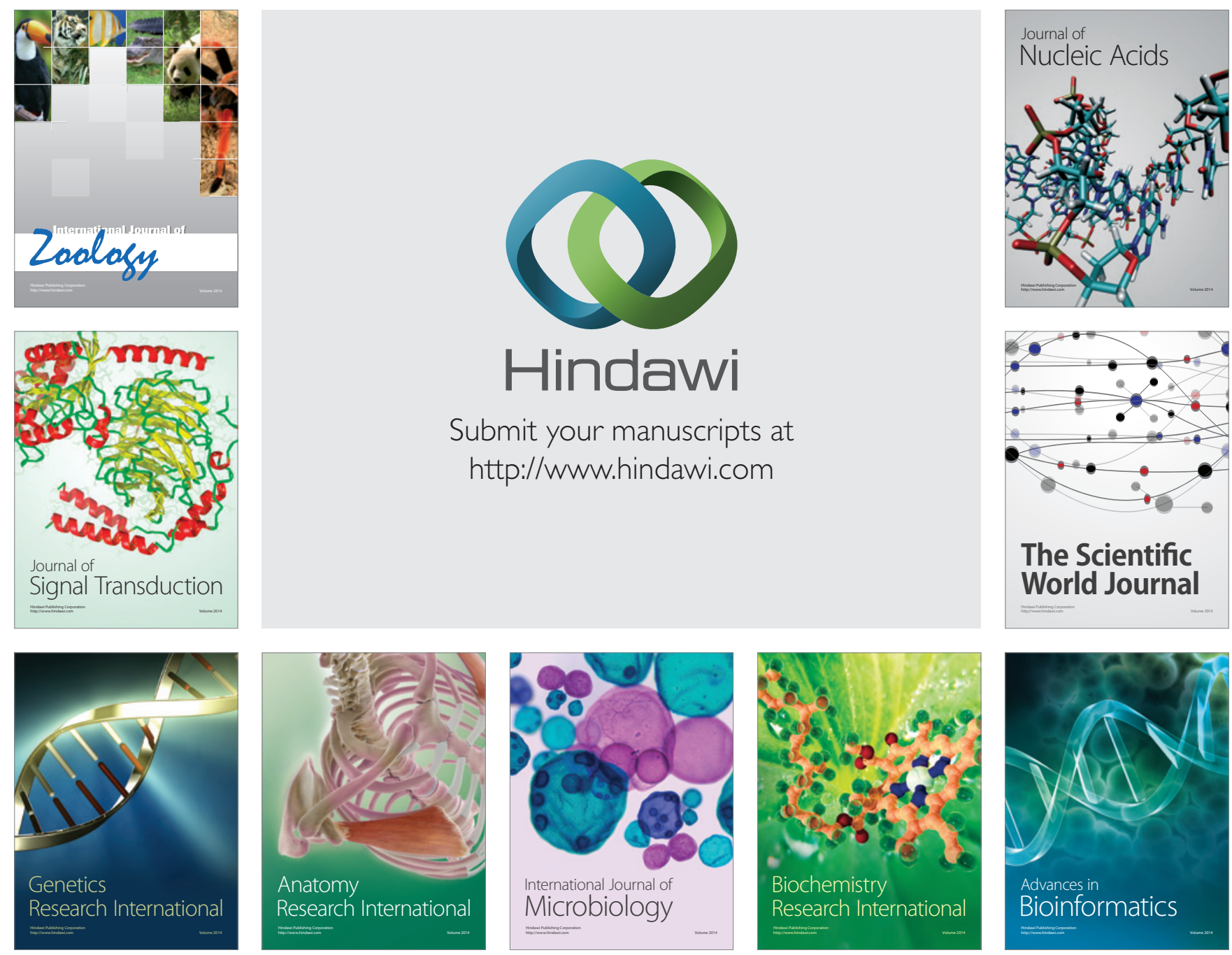

The Scientific World Journal
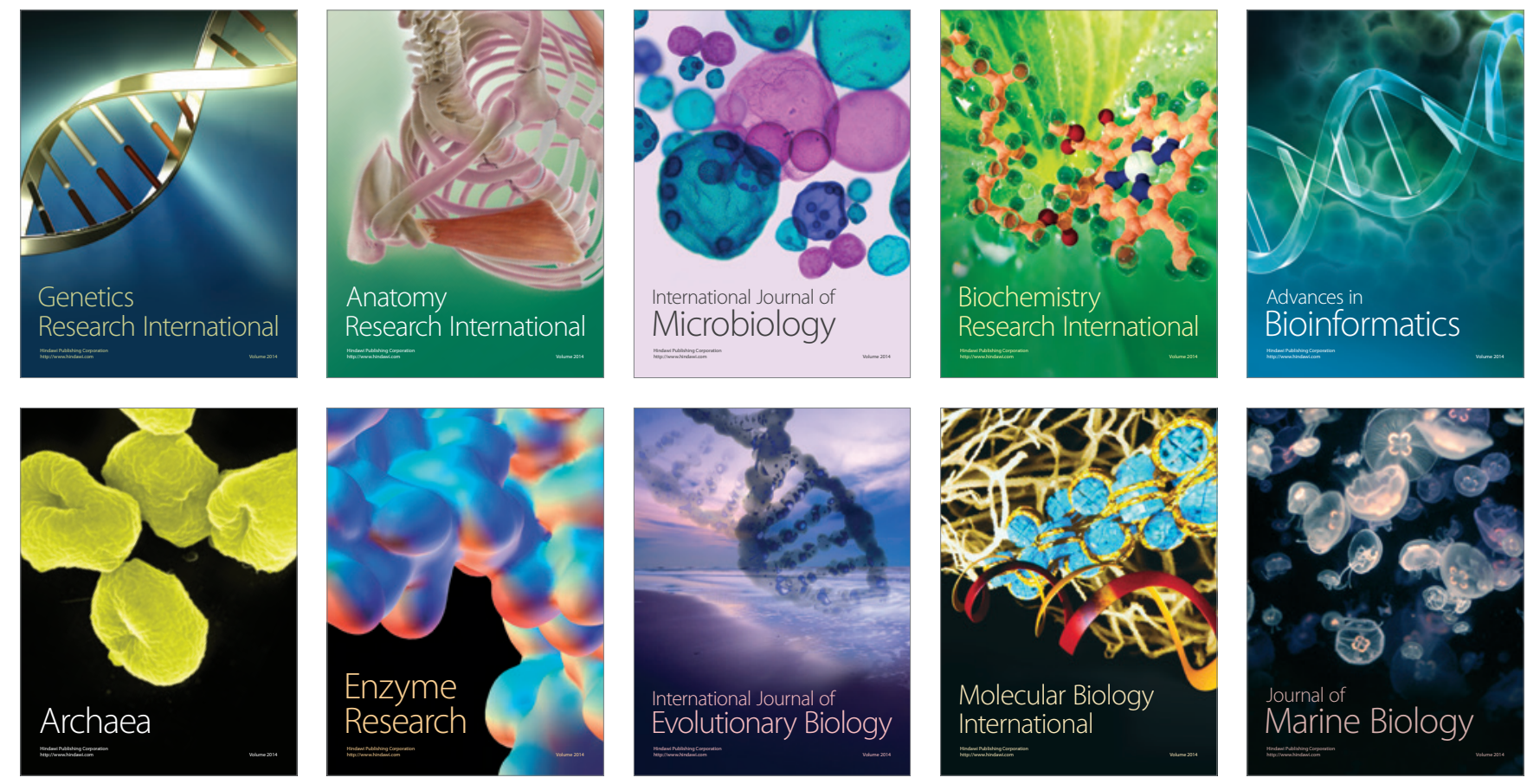